\title{
Perancangan Boost Converter Untuk Sistem Pembangkit Listrik Tenaga Surya
}

\author{
Ahmad Fathurachman, Asep Najmurrokhman, Kusnandar \\ Jurusan Teknik Elektro, Fakultas Teknik \\ Universitas Jenderal Achmad Yani \\ Jl. Terusan Jendral Sudirman PO Box 148 Cimahi 40533 \\ afathurachman@gmail.com; asepnajmu@yahoo.com; koes_kusnandar@yahoo.com
}

\begin{abstract}
Abstrak-Makalah ini menguraikan tentang perancangan sebuah penaik tegangan $D C$-to-DC Converter atau yang lebih dikenal dengan istilah boost converter untuk diimplementasikan dalam sistem pembangkit listrik tenaga surya. Rangkaian boost converter terdiri atas dua bagian penting yaitu rangkaian PWM sebagai rangkaian pembangkit arus untuk menghasilkan gelombang kotak (pulse) sebagai pengatur switch on dan switch off dan rangkaian pembangkit atau boost sebagai penaik tegangan. Tujuan dari rangkaian tersebut adalah untuk menghasilkan tegangan keluaran yang lebih besar dari tegangan masukan. Pada penelitian ini dilakukan langkah-langkah sebagai berikut : pendefinisian masalah, perencanaan rangkaian boost converter secara keseluruhan, dan implementasi. Berdasarkan spesifikasi yang telah ditentukan dilakukan perencanaan komponenkomponen yang akan digunakan dalam rangkaian boost converter. Hasil rancang bangun kemudian diuji untuk mengetahui nilai tegangan keluaran panel surya sebagai tegangan masukan boost converter dan tegangan keluaran boost converter, kemudian hasilnya dibandingkan dengan nilai ideal hasil perhitungan untuk mengetahui kinerja dari rangkaian boost converter hasil perancangan. Dari hasil pengujian diketahui rata-rata tegangan keluaran panel surya adalah $13,28 \mathrm{~V}$ dan rata-rata nilai tegangan keluaran boost converter adalah 36,3V. Rangkaian boost converter yang dibuat memiliki kinerja yang stabil dengan tegangan keluaran yang lebih besar 2,7 kali dari tegangan masukan.
\end{abstract}

Kata kunci-DC-DC Converter; boost converter; PWM; Pembangkit Listrik Tenaga Surya.

\section{Pendahuluan}

Energi listrik merupakan energi yang sangat dibutuhkan dalam menunjang kehidupan manusia dewasa ini. Saat ini, energi listrik dapat dikatakan menjadi kebutuhan primer masyarakat Indonesia, baik yang tinggal di kota besar maupun yang menetap di pelosok atau pedesaan. Indonesia merupakan negara yang banyak memiliki pulau serta pegunungan dimana disebagian daerah-daerah tersebut merupakan daerah yang terpencil dan tidak mendapat pasokan energi listrik yang cukup akibat sulitnya instalasi untuk menyalurkan energi listrik dari sumber pembangkit yang letaknya sangat jauh. Dengan kondisi tersebut, pemerintah mendorong upaya pengembangan penyediaan energi listrik dari sumber-sumber energi terbaharukan. Upaya tersebut selain dapat mengurangi beban listrik yang ditanggung oleh pemerintah juga dapat mengurangi emisi polutan yang dihasilkan akibat penggunaan bahan bakar fosil dalam mendukung kerja pembangkit energi listrik. Salahsatu sumber energi terbaharukan yang sangat besar adalah energi matahari. Pemanfaatan energi matahari sebagai sumber pembangkit listrik memiliki potensi yang sangat besar karena letak Indonesia yang berada didaerah tropis, yang dilewati oleh garis khatulistiwa dimana matahari bersinar sepanjang waktu. Untuk memanfaatkan potensi energi matahari sebagai sumber energi listrik diperlukan sel surya (solar cell) sebagai piranti untuk mengkonversi energi matahari menjadi energi listrik.

Melalui survey literatur, Najmurrokhman dkk. (2010) melaporkan bahwa faktor efisiensi merupakan tantangan terbesar dalam pemanfaatan energi matahari menjadi energi listrik [1]. Beberapa peneliti telah berupaya membangun suatu teknik untuk meningkatkan faktor efisiensi ini. Sarker, et al. (2010) telah merancang sistem penjejak matahari sesuai dengan arah datangnya cahaya matahari, sehingga diperoleh peningkatan energi matahari sebesar $30 \%$ yang berhasil diubah menjadi energi listrik [2]. Karp, et al. (2010) merancang sebuah sistem konsentrator cahaya matahari sehingga diperoleh efisiensi energi matahari yang diserap untuk dikonversikan menjadi energi listrik sebesar $90 \%$ [3]. Sementara itu, Khatib, et al. (2009) merancang sebuah pengendali elektromekanik yang berfungsi menjejak cahaya matahari supaya diperoleh energi matahari yang maksimum dan berdasarkan hasil penelitiannya diperoleh energi matahari hingga $60 \%$ [4]. Di lain pihak, dalam sejumlah aplikasi, daya yang dihasilkan dari sebuah modul surya tidak memadai, sehingga diperlukan penggabungan beberapa modul surya untuk mendapatkan level arus dan tegangan yang diinginkan. Penggabungan modul surya tersebut disusun dengan cara memparalel susunan koneksi seri dari modul surya (photovoltaic string). Namun demikian, cara tersebut tidak selalu menghasilkan output daya yang diharapkan, karena kondisi ketidaksesuaian (mismatching) antara string modul surya. Xiaoli, dkk (2011) menguraikan faktor-faktor penyebab ketidaksesuaian tersebut di antaranya karakteristik listrik dari setiap modul surya tidak identik, perbedaan dalam orientasi dan arah datang sinar matahari ke setiap modul surya, dan sebagainya [5]. Kondisi ketidaksesuaian antar modul surya menyebabkan daya hilang (losses) hampir 25\% dalam menghasilkan energi listriknya [6]. Daya hilang tersebut 
diakibatkan kegagalan memperoleh nilai MPPT (maximum power point tracking) dari setiap modul surya karena kondisi operasi yang tidak sesuai. Untuk menanganinya, rangkaian elektronika daya yang disebut $D C$-DC Converter yang sesuai harus dirancang agar dapat mengkompensasi nilai tersebut.

Makalah ini memaparkan tentang perancangan sebuah tipe $D C-D C$ Converter yang disebut boost converter yang berfungsi menstabilkan tegangan dengan menaikkan tegangan dimana tegangan keluaran lebih tinggi dari tegangan masukan tanpa harus menghilangkan daya yang relatif besar sehingga dapat mengatasi kekurangan tegangan. Konverter DC-DC hanya mengubah level tegangan dan level arus keluaran DC, tanpa mengubah daya selama proses konversi bentuk energi listriknya. Gambar 1 memperlihatkan secara skematik prinsip pengubahan tegangan oleh $D C-D C$ converter. Pada sebuah $D C-D C$ Converter dengan tegangan input yang ditentukan, besar tegangan output dikendalikan dengan durasi pensaklaran $\left(\mathrm{T}_{\text {on }}\right.$ dan $\left.\mathrm{T}_{\text {off }}\right)$ seperti diperlihatkan pada Gambar 2 .

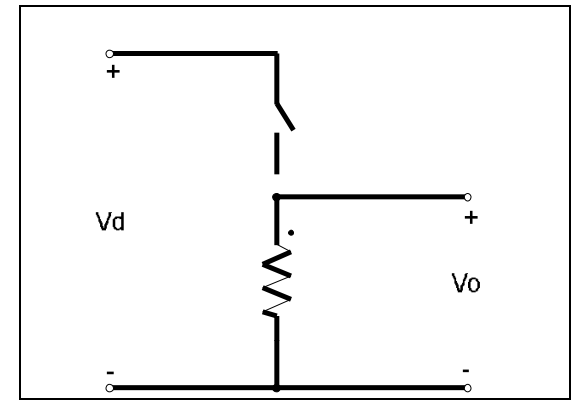

Gambar 1. Skema dasar DC-DC Converter

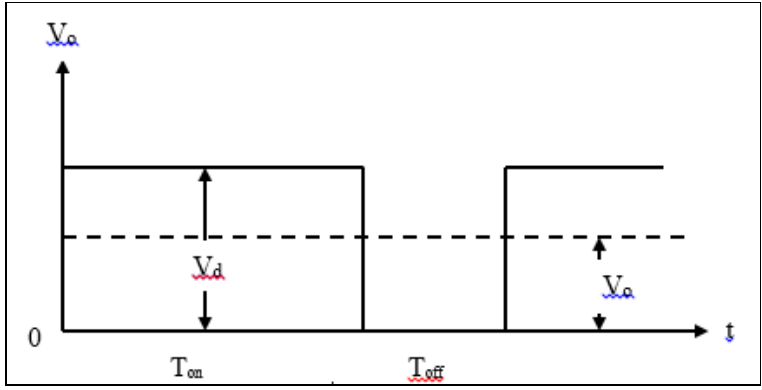

Gambar 2. Bentuk sinyal tegangan keluaran DC-DC Converter

Pengendalian dilakukan dengan memberikan sinyal / tegangan yang mengatur waktu ON dan waktu OFF switch. Sinyal tegangan yang berfungsi untuk mengatur switch biasanya menggunakan PWM ( Pulse Width Modulation ).

Boost Converter (Step-Up Converter) merupakan DC to $D C$ converter yang menghasilkan tegangan output yang jauh lebih besar dari tegangan inputnya. Boost Converter ini termasuk ke dalam rangkaian Switched-Mode Power Supply (SMPS) yang setidaknya terdapat dua switch semikonduktor seperti dioda dan transistor serta setidaknya satu komponen penyimpan energi seperti kapasitor atau induktor atau kombinasi keduanya. Filter yang dibuat dengan kapasitor atau terkadang juga dengan induktor biasanya disimpan pada output dari konverter tersebut untuk mengurangi tegangan ripple [7]. Skema rangkaian boost converter diberikan pada Gambar 3.

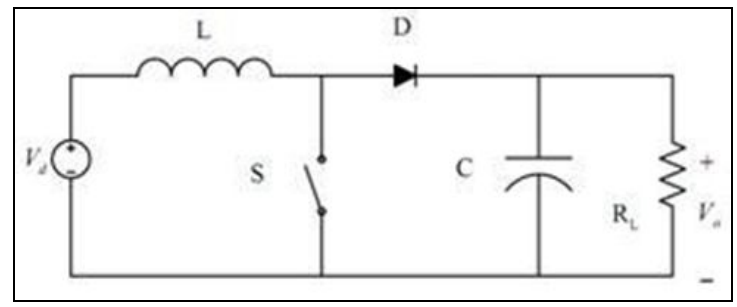

Gambar 3. Rangkaian Boost Converter [8]

Jika saklar dalam kondisi tertutup arus akan mengalir ke induktor sehingga menyebabkan energi yang tersimpan di induktor naik. Saat saklar terbuka, arus induktor akan mengalir menuju beban melewati dioda sehingga energi yang tersimpan di induktor akan turun. Rasio antara tegangan keluaran dan tegangan masukan sebanding dengan rasio antara periode pensaklaran dan waktu pembukaan saklar, yang disebut dengan duty cycle. Jika $\mathrm{D}=$ duty cycle, maka hubungan antarat tegangan masukan $\mathrm{V}_{\mathrm{d}}$ dan tegangan keluaran $\mathrm{V}_{\mathrm{o}}$ dinyatakan dengan persamaan (1) berikut

$$
\frac{V_{o}}{V_{d}}=\frac{1}{1-D}
$$

Nilai duty cycle akan mempengaruhi nilai tegangan output. Perbandingan duty cycle antara keadaan saklar terbuka dan saklar tertutup diberikan pada Gambar 4. Tegangan yang dihasilkan merupakan nilai rata-rata dari keadaan saklar yang terbuka dan tertutup.

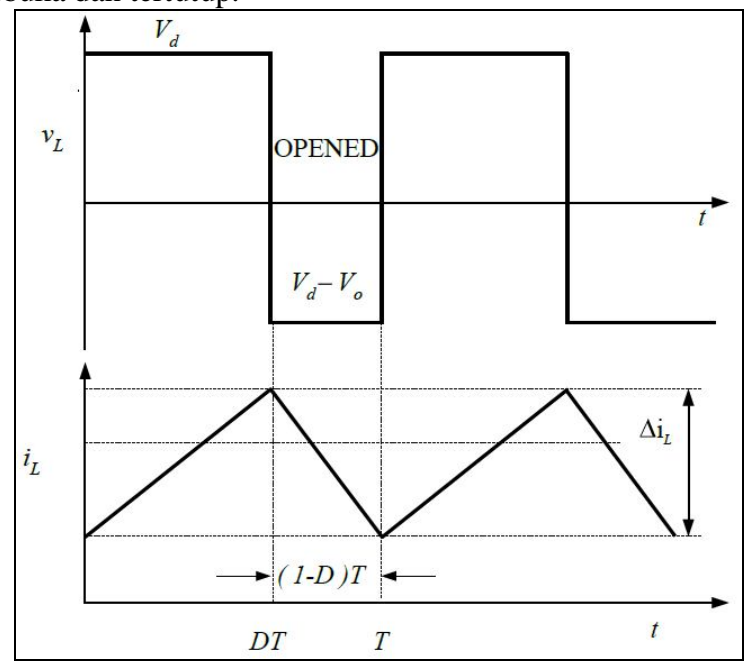

Gambar 4. Pengaruh duty cycle pada boost converter

Teknik pemberian pulsa pada DC-DC Converter menggunakan metode pulse width modulation (PWM) yang berfungsi sebagai switching power supply untuk mengontrol 
on dan off saklar. Pada PWM switching terdapat suatu switching frekuensi yang konstan. Switch control signal dengan control $\mathrm{ON}$ atau OFF dihasilkan dengan membandingkan suatu level tegangan control signal dengan suatu bentuk gelombang berulang. Frekuensi tetap konstan dalam suatu kontrol Pulse Width Modulator (PWM) dengan batasan rentang frekuensi yang ditentukan [9].

\section{Metode}

Diagram blok umum sebuah pembangkit tenaga surya diperlihatkan pada Gambar 5.

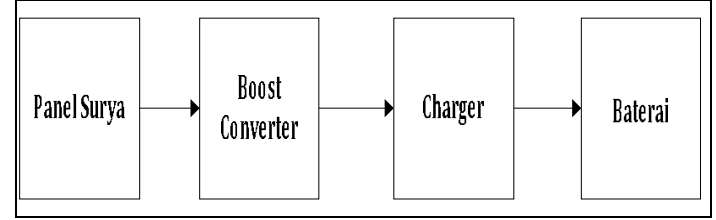

Gambar 5. Diagram blok Sistem PLTS

Dalam makalah ini, fokus penelitian diarahkan kepada perancangan boost converter. Panel surya yang digunakan dalam penelitian ini adalah panel surya yang telah ada di pasaran dengan nilai tegangan input $12 \mathrm{~V}$ dan daya puncak sebesar $3 \mathrm{~W}$. Pada rangkaian boost conveter yang dirancang terdapat dua bagian penting yaitu rangkaian pembangkit arus atau yang lebih dikenal dengan Pulse Width Modulation (PWM) untuk menghasilkan gelombang kotak (pulse) sebagai pengatur switch on dan switch off yang pada perencangan ini frekuensi dari PWM ditentukan sebesar $40 \mathrm{kHz}$, dan rangkaian pembangkit atau boost sebagai penaik tegangan. Diagram blok dasar dari sebuah rangkaian $D C$-DC Converter dengan jenis boost converter diberikan pada Gambar 6.

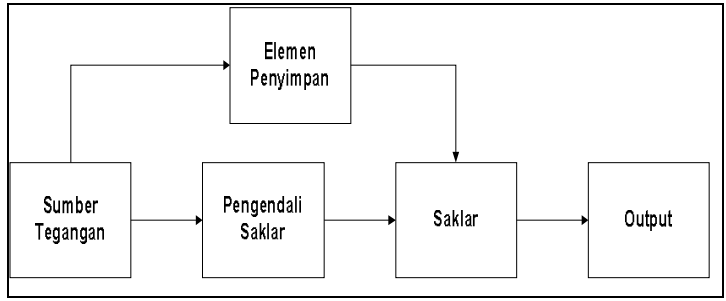

Gambar 6. Diagram blok boost converter

Skema rangkaian boost converter diperlihatkan pada Gambar 7. Dalam perancangan boost converter terdapat beberapa faktor utama yang harus diperhatikan di antaranya adalah variabel awal dalam merancang rangkaian boost converter yang pada nantinya digunakan sebagai parameter perhitungan untuk mendapatkan nilai besaran komponen-komponen lain seperti duty cycle, resistor, induktor, dan kapasitor. Variabel awal yang ditentukan dalam perancangan rangkaian boost converter ditentukan berdasarkan komponen yang tersedia di pasaran sesuai dengan spesifikasi yang diinginkan. Spesifikasi panel surya yang digunakan dalam penelitian ini adalah memiliki rentang tegangan keluaran antara $13-14,4 \mathrm{~V}$ serta daya puncak sebesar $3 \mathrm{~W}$, sedangkan tegangan keluaran boost converter diharapkan sebesar $36 \mathrm{~V}$. Dengan menggunakan persamaan (1), nilai duty cycle D untuk rangkaian ini dihitung menggunakan persamaan (2) berikut

$$
D=1-\frac{13}{36}=0,64
$$

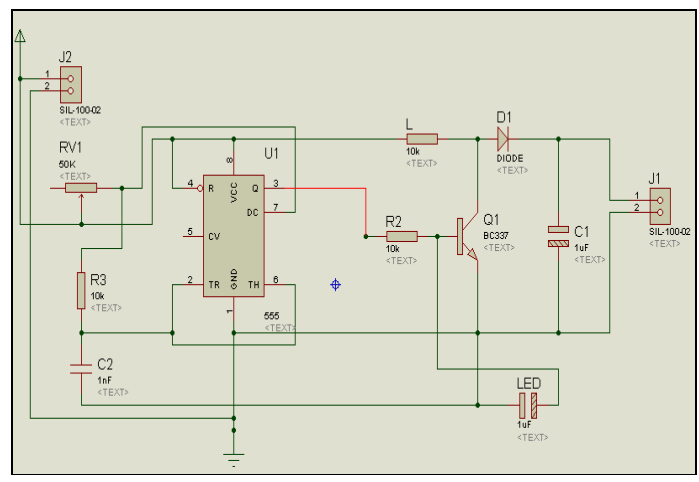

Gambar 7. Skema Rangkaian Boost Converter

Komponen berikutnya yang harus ditentukan adalah resistor pada kaki basis transistor. Besar nilai tahanan yang digunakan dalam rangkaian boost converter ditentukan dengan menggunakan perhitungan dalam persamaan (3).

$$
R=\frac{V_{o}}{I}=\frac{36 V}{0,25 \mathrm{~A}}=144 \Omega
$$

Induktor yang dipasang pada rangkaian boost converter berguna sebagai penguat tegangan setelah proses switching. Besar nilai minimal induktor yang digunakan dalam rangkaian boost converter ditentukan dengan menggunakan perhitungan dalam persamaan (4) berikut

$$
L_{\text {min }}=\frac{D(1-D)^{2} R}{2 f}
$$

dengan $D$ menyatakan duty cycle, $R$ adalah nilai tahanan pada kaki basis transistor, dan $f$ merupakan besar frekuensi PWM. Dari data yang tersedia, nilai induktansi induktor yang digunakan sebesar $150 \mu \mathrm{H}$. Sementara itu, sebuah kapasitor yang dipasang pada rangkaian boost converter berguna sebagai filter untuk mengurangi noise pada tegangan output. Nilai kapasitansi ini dapat dihitung dengan menggunakan persamaan (5) berikut

$$
C=\frac{V_{o} D}{R \Delta V_{o} f}
$$

dengan $\Delta \mathrm{V}_{\mathrm{o}}$ menyatakan rentang tegangan keluaran yang diperbolehkan. Misalnya diasumsikan nilai tersebut berharga 0,03, nilai kapasitor yang digunakan dalam rangkaian boost converter ini akan berharga $133 \mu \mathrm{F}$. 


\section{HASIL DAN DISKUSI}

Hasil pengujian dari rangkaian boost converter ini adalah merupakan hasil akhir dari perancangan yang telah direalisasikan. Data pengukuran rangkaian boost converter di antaranya adalah tegangan masukan rangkaian boost converter $\left(\mathrm{V}_{\text {in }}\right)$, tegangan rangkaian $\mathrm{PWM}\left(\mathrm{V}_{\mathrm{PWM}}\right)$, dan tegangan keluaran rangkaian boost converter $\left(\mathrm{V}_{\text {out }}\right)$. Dari hasil pengukuran selama 10 menit pertama diperoleh data $V_{\text {in }}$ seperti diperlihatkan pada Tabel 1. Sementara itu, bentuk sinyal $\mathrm{V}_{\text {in }}$ diberikan dalam Gambar 8.

Tabel 1. Tegangan masukan boost converter $\left(\mathrm{V}_{\text {in }}\right)$

\begin{tabular}{|c|c|}
\hline Menit ke- & $\mathrm{V}_{\text {in }}$ \\
\hline 1 & 13,10 \\
\hline 2 & 13,10 \\
\hline 3 & 13,10 \\
\hline 4 & 13,30 \\
\hline 5 & 13,30 \\
\hline 6 & 13,30 \\
\hline 7 & 13,40 \\
\hline 8 & 13,40 \\
\hline 9 & 13,40 \\
\hline 10 & 13,40 \\
\hline Nilai rerata & 13,28 \\
\hline
\end{tabular}

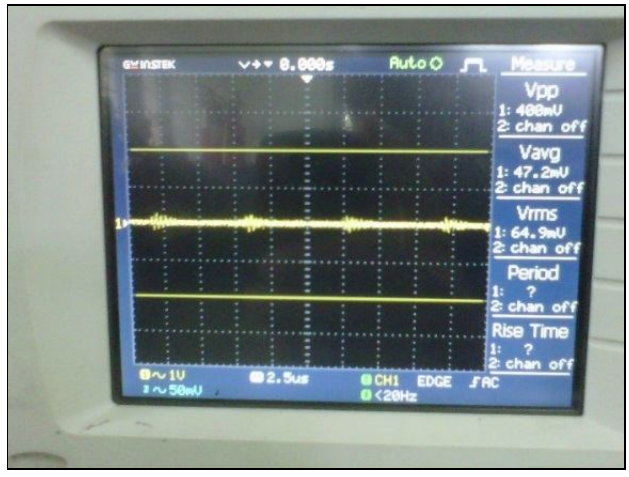

Gambar 8. Bentuk sinyal $V_{\text {in }}$

$\mathrm{V}_{\text {PWM }}$ merupakan tegangan keluaran dari IC Timer 555 atau juga dalam rangkaian ini disebut dengan tegangan keluaran rangkaian PWM yang memiliki bentuk sinyal kotak yang menjadi masukan bagi transistor pada rangkaian boost. Tegangan keluaran rangkaian PWM secara teoretis akan mencapai nilai $0,7 \mathrm{~V}$, karena tegangan keluaran dari rangkaian PWM ini menjadi masukan bagi transistor atau rangkaian boost yang memiliki tegangan saturasi $\left(\mathrm{V}_{\text {sat }}\right)=0,7 \mathrm{~V}$. Bentuk sinyal $\mathrm{V}_{\mathrm{PWM}}$ diperlihatkan dalam Gambar 9.

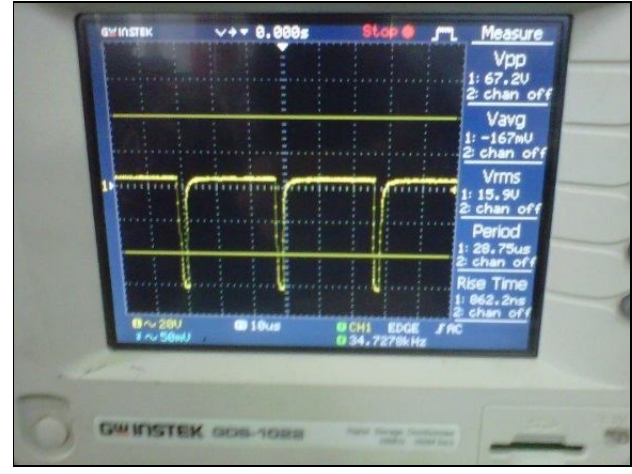

Gambar 9. Bentuk sinyal $\mathrm{V}_{\mathrm{ic}}$

Sementara itu, $\mathrm{V}_{\text {out }}$ merupakan tegangan keluaran dari rangkaian boost converter yang merupakan tegangan $\mathrm{V}_{\text {in }}$ yang telah distep up oleh rangkaian boost converter. Data pengujian $\mathrm{V}_{\text {out }}$ diambil selama 10 menit pertama dan diperoleh hasil seperti yang diperlihatkan pada Tabel 2. Bentuk sinyal $\mathrm{V}_{\text {out }}$ diberikan pada Gambar 10 yang memperlihatkan bahwa sinyalnya berbentuk searah.

Tabel 2. Tegangan keluaran boost converter $\left(\mathrm{V}_{\mathrm{out}}\right)$

\begin{tabular}{|c|l|}
\hline Menit ke - & $\mathrm{V}_{\text {out }}$ \\
\hline 1 & 36,2 \\
\hline 2 & 36,2 \\
\hline 3 & 36,2 \\
\hline 4 & 36,2 \\
\hline 5 & 36,3 \\
\hline 6 & 36,3 \\
\hline 7 & 36,4 \\
\hline 8 & 36,4 \\
\hline 9 & 36,4 \\
\hline 10 & 36,4 \\
\hline Nilai rerata & 36,3 \\
\hline
\end{tabular}

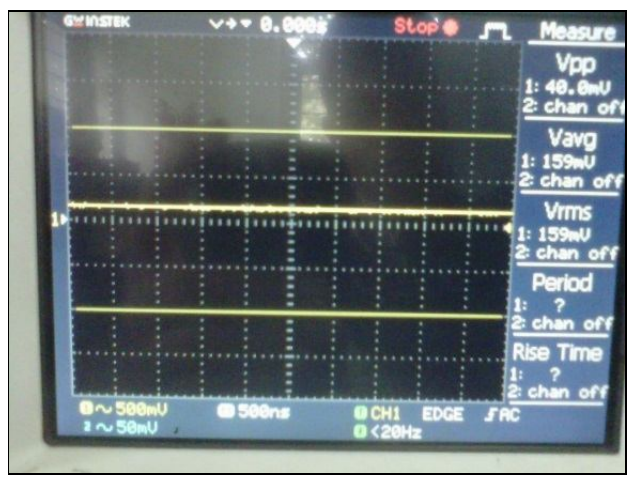

Gambar 10. Bentuk sinyal $\mathrm{V}_{\text {out }}$ 
Dalam penelitian ada beberapa parameter yang dapat dihitung secara teoritis sebagai asumsi nilai ideal dari rangkaian boost converter yang dibuat. Parameter-parameter yang dihitung di antaranya adalah perioda PWM (T), tegangan keluaran rangkaian boost converter $\left(\mathrm{V}_{\text {out }}\right)$, dan ripple tegangan keluaran rangkaian boost converter (r). Dengan nilai frekuensi PWM sebesar $40 \mathrm{kHz}$, perioda pensaklarannya berharga $1 / \mathrm{T}$ atau $25 \mu$ s. Sementara itu, dengan menggunakan persamaan (1), tegangan keluaran boost converter seharusnya berharga

$$
V_{o}=\frac{V_{\text {in }}}{1-D}=\frac{13,28}{1-0,64}=36,8 \mathrm{~V}
$$

Ripple tegangan keluaran dihitung menggunakan persamaan (6)

$$
r=\frac{D}{R C f}
$$

dan diperoleh nilai 0,000833, artinya ripple tegangan keluaran berharga $0,08 \%$ dari tegangan nominalnya.

Rangkaian yang dibuat pada penelitian ini adalah penaik tegangan berbasis step up voltage $D C$ to $D C$. Rangkaian ini banyak dikenal sebagai boost converter. Karena rangkaian ini merupakan penaik tegangan, maka tegangan output lebih besar hingga 4 kali lipat dari tegangan input. Penambahan induktor dan switching dari transistor mampu membangkitkan tegangan dengan mode switching. Pada rangkaian ini terdapat dua bagian penting, yaitu rangkaian pembangkit arus atau yang lebih dikenal dengan sebutan PWM dan rangkaian pembangkit tegangan atau boost. Pada bagian pertama, yaitu PWM menggunakan IC Timer 555 untuk menghasilkan gelombang kotak (pulse) sebagai pengatur proses switch on dan switch off. Proses switching dilakukan pada frekuensi $40 \mathrm{kHz}$ yang dihasilkan dari rangkaian PWM. Output dari PWM disambungkan pada kaki basis transistor sebagai pengatur switching. Dari hasil pengukuran menggunakan osiloskop diketahui terdapat riak tegangan (ripple) pada tegangan keluaran boost converter. Secara sistematis hal ini bisa terjadi karena tegangan masukan boost converter yang merupakan keluaran panel surya bukan tegangan DC murni dan pada penelitian ini boost converter tidak diberi tambahan rangkaian filter secara khusus. Dalam pengujian rangkaian boost converter yang dibuat dapat dibuktikan menghasilkan rangkaian yang cukup stabil. Dengan pengambilan sampel data pengujian rangkaian selama 10 menit diperoleh rata-rata tegangan keluaran sebesar $36,3 \mathrm{~V}$, mendekati hasil perhitungan dengan nilai ideal tegangan keluar sebesar 36,8 V. Hal demikian dapat terjadi karena pengaruh beberapa faktor seperti tegangan masukan yang berasal dari panel surya yang bisa berfluktuasi dan hasil pengukuran membuktikan bahwa rangkaian yang dibuat bekerja sesuai dengan harapan dengan tegangan keluaran 2,7 kali tegangan input. Secara keseluruhan rangkaian boost converter yang dibuat dapat menaikkan tegangan masukan yang berasal dari panel surya yang besarnya $13,28 \mathrm{~V}$ menjadi $36,3 \mathrm{~V}$ dan dapat bekerja dengan stabil sesuai dengan perumusan masalah dan tujuan penelitiannya.

\section{KESIMPULAN}

Makalah ini telah menguraikan tentang perancangan boost converter untuk diterapkan dalam skema penguat tegangan dari pembangkit listrik tenaga surya. Dari hasil penelitian yang dilakukan diperoleh bahwa rangkaian yang dibangun memperlihatkan kinerja yang baik dengan ditunjukkan oleh nilai penguatan sebesar 2,7 kali sesuai dengan tujuan perancangannya. Selain itu, nilai ripple tegangan keluaran yang sangat kecil memperlihatkan bahwa komponen filter yang digunakan relatif berhasil menekan komponen sinyal non DC yang masuk ke dalam sistem.

Untuk menyempurnakan hasil-hasil yang diperoleh, penelitian lanjutan diperlukan agar rangkaian yang dirancang dapat diterapkan dalam sistem nyata. Salahsatu arah penelitian yang dapat ditindaklanjuti adalah penerapan teknik kendali dalam perancangan boost converter untuk menangani adanya parameter tersembunyi dalam sistem serta agar dapat diperoleh hasil tegangan keluaran dengan tingkat akurasi yang sangat tinggi seperti yang diusulkan oleh Tan dkk. [10].

\section{UCAPAN TERIMA KASIH}

Terima kasih disampaikan kepada LPPM Unjani yang telah membiayai sebagian penelitian ini dalam skema hibah Penelitian Unggulan Tahun Anggaran 2014.

\section{DAFTAR PUSTAKA}

[1] A. Najmurrokhman dan M. Fajrin, "Prototipe Penjejak Cahaya Matahari untuk Mempertinggi Efisiensi Penyerapan Energi Matahari pada Solar Cell, Prosiding Seminar Nasional Energi, Jurusan Fisika Unpad, 3 November $2010 \mathrm{hlm} .145-150$.

[2] M. R. I. Sarker, Md. Riaz Pervez, and R.A Beg, "Design, Fabrication and Experimental Study of a Novel Two-Axis Sun Tracker", International Journal of Mechanical \& Mechatronics Engineering IJMME-IJENS Vol. 10 No. 01, ISSN: 2077-124X, February 2010, pp. $13-18$

[3] J. H. Karp, E. J. Tremblay, and J. E. Ford, "Planar micro-optic solar concentrator, Optics Express, Vol. 18, Issue 2, 2010, pp. 1122-1133.

[4] T. T. N. Khatib, A. Mohamed, R.J. Khan and N. Amin, "A novel active sun tracking controller for photovoltaic panels". J. Applied Sci., 9, 2009, pp. $4050-4055$

[5] X. Xiaoli dan Q. Daoe, "Remote Monitoring and Control of Photovoltaic System Using Wireless Sensor Network", International Conference on Electric Information and Control Engineering (ICEICE), Wuhan, China, 15-17 April 2011, pp. 633-638.

[6] E. Roman, E., et al., "Intelligent PV Module for Grid-connected PV Systems", IEEE Trans. on Industrial Electronics, vol. 53, no. 4, April 2006, pp. 1066-1073.

[7] M. H. Rashid, "Power Electronics : Circuit, Devices and Applications", Prentice Hall, 2001.

[8] N. Mohan and W. P. Robbins, "Power Electronics: Converters, Applications, and Design (3rd ed.)", John Wiley\&Sons, NY, 2003.

[9] M. Kazimierczuk, "Pulse Width Modulated DC-DC Power Converters", PhD thesis, Wright State University Dayton, Ohio, USA, 2008.

[10] S.C. Tan, Y.M. Lai, and C.K. Tse, "Sliding Mode Control of Switching Power Converter", CRC Press, 2012. 